\title{
PENGARUH PELAKSANAAN SUPERVISI PENDIDIKAN \\ OLEH KEPALA SEKOLAH TERHADAP \\ KINERJA GURU
}

\author{
ELGA YOLANDHIKA \\ Email: yolandhikaga@gmail.com
}

\begin{abstract}
ABSTRAK
Pelaksanaan supervisi pendidikan oleh kepala sekolah bertujuan untuk meningkatkan kualitas belajar mengajar di sekolah dan mengetahui proses penyusunan program supervisi dalam meningkatkan kompetisi profesional guru. Tujuan penelitian ini adalah untuk mengetahui pengaruh supervisi yang dilakukan Kepala Sekolah terhadap Kinerja Guru. Fungsi pendidikan nasional adalah mengembangkan kemampuan dan membentuk watak peserta didik agar menjadi manusia yang beriman dan bertakwa, berakhlak mulia, mandiri dan menjadi warga Negara yang demokratis serta bertanggung jawab.
\end{abstract}

Kata Kunci : supervisi, pendidikan, kinerja guru

\section{LATAR BELAKANG}

Supervisi pendidikan dapat didefinisikan secara etimologis, supervisi berasal dari bahasa Inggris supervision. Super berarti di atas, sedangkan vision berarti penglihatan / melihat. Dan jika diartikan secara bebas, maka supervision dapat pula dimaknai sebagai melihat dari atas.

Di Indonesia, fungsi pendidikan secara nasional dirumuskan dalam UU nomor 20 Tahun 2003. Di dalamnya dijelaskan bahwa fungsi pendidikan nasional adalah mengembangkan kemampuan dan membentuk watak serta peradaban bangsa yang bermanfaat dalam rangka mencerdaskan kehidupan bangsa, bertujuan untuk berkembangnya potensi peserta didik agar menjadi manusia yang beriman dan bertakwa kepada Tuhan Yang Maha Esa, berakhlak mulia, sehat, berilmu, cakap, kreatif, mandiri dan menjadi warga Negara yang demokratis serta bertanggung jawab.

Dalam rangka mencapai suatu pendidikan yang berkualitas terutama di tingkat pendidikan dasar maka perlu upaya mengoptimalkan kualitas sumber daya pendidikan. Salah satu sumber daya tersebut adalah tenaga yang bergerak sebagai tenaga kependidikan. Baik itu meliputi komponen teratas di tingkat kementrian sampai di tingkat terdepan yaitu sekolah. Guru adalah salah satu komponen sumber daya pendidikan yang ada di sekolah.

Pengembangan profesi guru dilaksanakan melalui berbagai program pendidikan, prajabatan, maupun program dalam jabatan. Namun, tidak semua guru yang dididik dalam berbagai program tersebut menunjukkan kinerja yang mumpuni. Untuk menjaga kualitas 
kinerja guru maka perlu adanya quality qontrol dalam bentuk supervisi pendidikan terhadap guru-guru di sekolah.

Supervisi pendidikan terbagi menjadi dua yaitu supervisi akademik dan supervisi manajerial. Supervisi akademik adalah supervisi terhadap guru dalam proses belajar mengajar meliputi perencanaan program, pelaksanaan program pembelajaran dan evaluasi program pembelajaran. Sedangkan supervisi manajerial adalah program supervisi terhadap kinerja kepala sekolah di masing-masing satuan pendidikan. Dalam praktiknya, supervisi akademik diberikan oleh kepala sekolah kepada guru dalam rangka memperbaiki kinerja, hal ini berdasarkan pernyataan Pupuh Fathurrohman (2011:8) bahwa pada dasarnya supervisi pendidikan dapat diartikan sebagai bantuan yang diberikan oleh kepala sekolah untuk melaksanakan penilaian dan supervisi dari segi teknis pendidikan dan administrasi dalam bentuk arahan bimbingan dan contoh pelaksanaan mengajar.

Berdasarkan uraian di atas, permasalahan di tulisan ini adalah (1).Bagaimana kondisi pendidikan yang seharusnya terjadi? (2) Bagaimana cara meningkatkan mutu pendidikan melalui supervisi pendidikan ? Tujuan tulisan ini adalah untuk mengetahui cara-cara yang dapat dilakukan meningkatkan mutu pendidikan melalui supervisi pendidikan ?

\section{PEMBAHASAN}

\section{Kondisi pendidikan yang seharusnya terjadi}

Menurut Mulyasa (2013: 88) kinerja guru diartikan sebagai "unjuk kerja seseorang yang ditunjukkan dalam penampilan, perbuatan, dan prestasi kerjanya sebagai akumulasi dari pengetahuan, keterampilan, nilai dan sikap yang telah di miliki". Sedangkan menurut Mustofa (2013: 156) menjelaskan kinerja atau performance merupakan hasil kerja yang dapat dicapai oleh seseorang atau sekelompok orang dalam suatu organisasi, sesuai dengan wewenang dan tanggung jawab masing-masing, dalam rangka upaya mencapai tujuan organisasi secara legal, tidak melanggar hukum dan sesuai dengan moral etika.

Kinerja yang dimaksudkan adalah kinerja dari seorang guru. Mustofa (2013: 156) memberikan definisi bahwa "kinerja guru adalah hasil kerja yang dapat dicapai oleh seorang guru di lembaga pendidikan atau madrasah sesuai dengan tugas dan tanggung jawabnya dalam mencapai tujuan pendidikan".

Secara lebih rinci dijelaskan dalam Undang-Undang RI nomor 14 tahun 2005 tentang Guru dan Dosen, yaitu "Guru adalah pendidik professional dengan tugas utama mendidik, mengajar, membimbing, mengarahkan, melatih dan mengevaluasi peserta didik pada pendidik usia dini jalue pendidikan formal, pendidikan dasar, dan pendidikan menengah”.

Dari definisi-definisi diatas dapat disimpulkan bahwa kinerja guru merupakan suatu unjuk kerja atau performance dari seseorang yang memiliki kualifikasi sebagai tenaga pendidik di suatu lembaga pendidikan dimana unjuk kerja tersebut ditujukan untuk mencapai tujuan pendidikan. Unjuk kerja guru tersebut merupakan perwujudan dari berbagai pengetahuan, sikap, dan keterampilannya yang didapat dari berbagai proses yang menjadikannya sebagai seorang guru. 


\section{Faktor-faktor yang Mempengaruhi Kinerja Guru}

Faktor-faktor yang dapat Mempengaruhi Kinerja Guru adalah faktor dari dalam meliputi pendidikan dari sang guru, pengalaman, keterampilan, motivasi serta kepribadian dari guru itu sendiri. Sedangkan faktor dari luar meliputi kondisi di lingkungan kerja, jumlah gaji, bahkan juga faktor kepemimpinan dari kepala lembaga atau dalam hal ini kepala sekolah itu sendiri. Maka dari itu, sangatlah penting bagi seorang kepala sekolah untuk mengetahui dengan benar apa yang menjadi penyebab kinerja guru menurun atau meningkat. Dengan memastikan hal tersebut, maka guru bersama sekolah dapat secara efektif membangun iklim kerja yang kondusif sehingga kinerja guru dapat optimal. Meningkatkan supervise pendidikan oleh kepala sekolah yang dikemukakan oleh sabandi. (sabandi, 2013)

\section{Penilaian Kinerja Guru}

Untuk menilai kinerja guru, maka di lingkungan pendidikan dikenal istilah Penilaian Kinerja Guru (PKG). PKG merupakan suatu kegiatan untuk membina dan mengembangkan guru professional yang dilakukan dari guru, oleh guru dan untuk guru.

Konsep PKG salah satunya diatur menurut Peraturan Menteri Negara Pendayagunaan Aparatur Negara dan Reformasi Birokrasi Nomor 16 Tahun 2009 tentang Jabatan Fungsional Guru dan Angka Kreditnya. Di dalamnya dijelaskan bahwa PKG adalah penilaian dari tiap butir kegiatann tugas utama guru dalam rangka pembinaan karier, kepangkatan dan jabatannya. PKG tidak hanya dilaksanakan bagi guru-guru yang berada di bawah naungan Kementrian Pendidikan dan Kebudayaan, tetapi juga berlaku untuk guru-guru yang berada di bawah Kementrian Agama.

"Sistem PKG adalah sistem yang dirancang untuk mengidentifikasi kemampuan guru dalam melaksanakan tugasnya melalui pengukuran penguasaan kompetensi yang ditunjukkan dalam kinerjanya" (Nanang Priatna, 2013: 1). Maka sebagai guru sangatlah penting untuk benarbenar memahami konsep PKG secara detail. Apabila dulu PKG hanya mencakup fungsi dan peran guru dalam kegiatan pembelajaran dan konseling, maka sekarang PKG lebih kompehensif mencakup unsur peranan guru di kelembagaan sekolah. Hasil penilaian akan dikumulatifkan dengan angka kredit guru itu sendiri.

\section{Aspek Penilaian Kinerja Guru}

Berdasarkan Peraturan Menteri Negara Pendayagunaan Aparatur Negara dan reformasi Nomor 16 Tahun 2009 tentang Jabatan Fungsional Guru dan angka Kreditnya, PKG dilakukan terhadap 3 aspek yaitu :

1) Unsur pembelajaran (bagi guru mata pelajaran/guru kelas)

2) Unsur pembimbingan (bagi guru konseling)

3) Tugas tambahan / tugas lain yang relevan yang didasarkan atas aspek kualitas, kuantitas, waktu dan biaya. 
Penilaian kinerja yang terkait dengan pelaksanaan proses pembelajaran bagi guru mata pelajaran atau guru kelas, meliputi kegiatan merencanakan dan melaksanakan pembelajaran, menilai, menganalisis hasil penilaian, dan melaksanakan hasil penilaian. Pengelolaan proses pembelajaran tersebut dengan berpedoman pada 4 (empat) syarat kompetensi, kompetensi yang dijadikan dasar untuk penilaian kinerja guru adalah (1) kompetensi pedagogik meliputi 7 aspek yang dinilai, (2) kompetensi kepribadian terdiri dari 3 aspek kompetensi yang dinilai, (3) kompetensi sosial dengan 2 aspek penilaian, serta (4) kompetensi professional yang memiliki 2 aspek penilaian. Selanjutnya aspek-aspek tersebut dijadikan indikator dalam penyusunan instrumen penelitian pada variabel kinerja guru.

Fungsi supervisi pendidikan antara lain:

(1) Dalam bidang kepemimpinan, guru dan kepala sekolah secara bersama-sama dapat menyusun program kegiatan pembelajaran dan kegiatan-kegiatan lain yang mendukung sesuai kapasitasnya masing-masing, (2) Dalam bidang hubungan kerja, dapat diketahuinya kekurangan dan kelebihan masing-masing melalui proses interaksi yang saling memberikan kontrol dan evaluasi, (3) Dalam bidang pembinaan personalia, berfungsi untuk memberikan pemahaman tentang penempatan, susunan kerja dan kondisi personalia, (4) Dari sisi evaluasi, supervisi berfungsi untuk melihat berbagai faktor yang mempengaruhi kualitas pembelajaran di sekolah meliputi faktor dari kepemimpinan kepala sekolah, kualitas guru, kondisi siswa serta ketersediaan sarana prasarana.

\section{Pengaruh Pelaksanaan Supervisi Pendidikan oleh Kepala Sekolah terhadap Kinerja Guru}

Supervisi dapat dilakukan oleh kepala sekolah yang berperan dalam membawa lembaga atau institusi yang dipimpinnya. Kepala sekolah bukan hanya mengawasi karyawan dan guru yang sedang melaksanakan kegiatan, tetapi ia membekali diri dengan pengetahuan dan pemahamannya tentang tugas dan fungsi stafnya, agar pengawasan dan pembinaan berjalan dengan baik dan tidak membingungkan.

Hadis \& Nurhayati (2010) memberikan pemaparannya, bahwa dalam kaitannya dengan kinerja guru, kepala sekolah sebagai supervisor merupakan mitra guru dalam memecahkan masalah pengajaran di kelas agar kinerja dan profesionalitas mereka dalam merencanakan, melaksanankan, mengevaluasi proses dan hasil pembelajaran menjadi meningkat.

\section{PENUTUP}

Kesimpulan

Berdasarkan pembahasan diatas disimpulkan bahwa tidak adanya pengaruh positif dari pelaksanaan supervisi pendidikan oleh kepala sekolah terhadap kinerja guru di sekolah. 
Hipotesis menyatakan bahwa "terdapat pengaruh yang positif dan signifikan pelaksanaan signifikan supervisi pendidikan oleh kepala sekolah terhadap kinerja guru” tidak terbukti.

Saran

Berdasarkan uraian diatas, maka disarankan agar guru lebih mampu memahami atasan maupun rekannya baik personal maupun professional. Walaupun terkadang guru dan atasan maupun guru dengan guru lainnya memiliki pamgkat yang sama, tapi guru tetap harus saling menghormati dan memposisikan kepala sekolah sebagai atasan, serta guru yang memiliki masa kerja lebih di pendidikannya sebagai sumber informasi dan belajar baginya.

\section{REFERENSI}

Sabandi, A. (2013). Supervisi Pendidikan Untuk Pengembangan Profesionalitas Guru Berkelanjutan. Pedagogi, Jurnal Ilmiah Ilmu Pendidikan , 1-9.

Abdul Hadis \& Nurhayati. (2010). Manajemen Mutu Pendidikan. Bandung: Alfabeta.

Hamzah. (2007). Profesi Kependidikan. Jakarta: Bumi Aksara.

Jasmani Asf \& Syaiful Mustofa. (2013). Supervisi Pendidikan: Terobosan Baru Dalam Peningkatan Kinerja Pengawas Sekolah Dan Guru. Yogyakarta: Graha Ilmu.

Nanang Priatna \& Tito Sukamto. (2013). Pengembangan Profesi Guru. Bandung: Remaja Rosdakarya.

Pupuh Fathurrohman \& Aa Suryana. (2011). Supervisi Pendidikan Dalam Pengembangan Proses Pembelajaran. Bandung: Refika Aditama. 